indicate that the foraging pattern of bees and consequently the neighborhood size in plant populations may be density related. The number of individuals comprising a neighborhood at high density would be greater than at very low densities. Neighborhood area would be greater at the low densities. (This is a direct consequence of the greater frequency of near neighbor moves at low densities.) This result must, however, be modified somewhat since at very low densities pollinator foraging trip length is quite short in relation to the high density population. At extremely low plant densities one may expect neighborhood size to again increase. The proportion of long distance flights is increased. The results of this study indicate that genetic structure in an entomophilous plant may be density related.

A final aspect of this study is related to the attractiveness of a population to pollinators. Populations of high density are presumably more attractive to pollinators since they offer more reward per unit area than populations of low densities. The data from the average number of plants visited per bee foraging trip are consistent with this hypothesis. The denser the population the greater is the proportion of the flower population visited per bee. At very low densities the experimental population attracted few bees and only few plants were visited while at high densities many bees were attracted and each plant was repeatedly visited.

\section{ACKNOWLEDGMENTS}

I thank W. J. Leverich, D. A. Levin and B. B. Simpson for critically reading the manuscript, E. H. Bryant for discussions and L. Marshall for assistance in the field. This study was supported by the University of Houston Coastal Center.

\section{Literature Cited}

Gaiser, L. C. 1946. The genus Liatris. Rhodora 48:165-412.

HeInRICH, B., AN'D P. H. Raven. 1972. Energetics and pollination ecology. Science 176: 597-602.

Levin, D. A., ANd H. W. Kerster. 1969a. Density-dependent gene dispersal in Liatris. Amer. Natur. 103:61-74.

- $1969 \mathrm{~b}$. The dependence of bee-mediated pollen and gene dispersal upon plant density. Evolution 23:560-571.

—_. 1974. Gene flow in seed plants. Evolutionary Biology 7:139-220.

SchaAI, B. A. 1974. Isolation by distance in Liatris cylindracea. Nature 252:703.

-1975. Population structure and local differentiation in Liatris cylindracea. Amer. Natur. 109:511-528.

WrIGHT, S. 1969. Evolution and the Genetics of Populations. Vol. 2. The Theory of Gene Frequencies. University of Chicago Press, Chicago.

Evolution, 32(2), 1978, pp. 454-456

\title{
EVOLUTIONARY TRANSITION FROM AMMONITE SUBPRIONOCYCLUS TO REESIDITES-PUNCTUATED OR GRADUAL?
}

\author{
Phitip D. Gingerich \\ Museum of Paleontology, The University of Michigan, Ann Arhor, Michigan 48109
}

Received February 1, 1977. Revised August 22, 1977

The actual evolutionary transition from one species to another in a natural environment can only be studied where a detailed fossil record is available. Several years ago Eldredge (1971) and Eldredge and Gould (1972) advanced an hypothesis that species should be relatively stable in the fossil record, and the evolutionary transition from one species to another should be abrupt. Their view of speciation differs considerably from the traditional paleontological view of dynamic species with gradual evolutionary transitions (Simpson, 1951; and others), but it can be tested by study of the fossil record. I have discussed Eldredge and Gould's "punctuated equilibria" model at length elsewhere, and provided some apparently contradictory examples from the fossil record of terrestrial mammals (Gingerich, 1976a, $1976 b)$. One of the examples from the marine fossil record cited by Gould and Eldredge (1977) as evidence favoring their "punctuated equilibria" model is the transition from the ammonite genus Subprionocyclus to Reesidites recently published by Reyment (1975). This example illustrates a fallacy in some analyses of evidence bearing on the question of species transitions, and it thus deserves further attention.

The distribution and morphology of Subprionocyclus and Reesidites are summarized in Reyment 


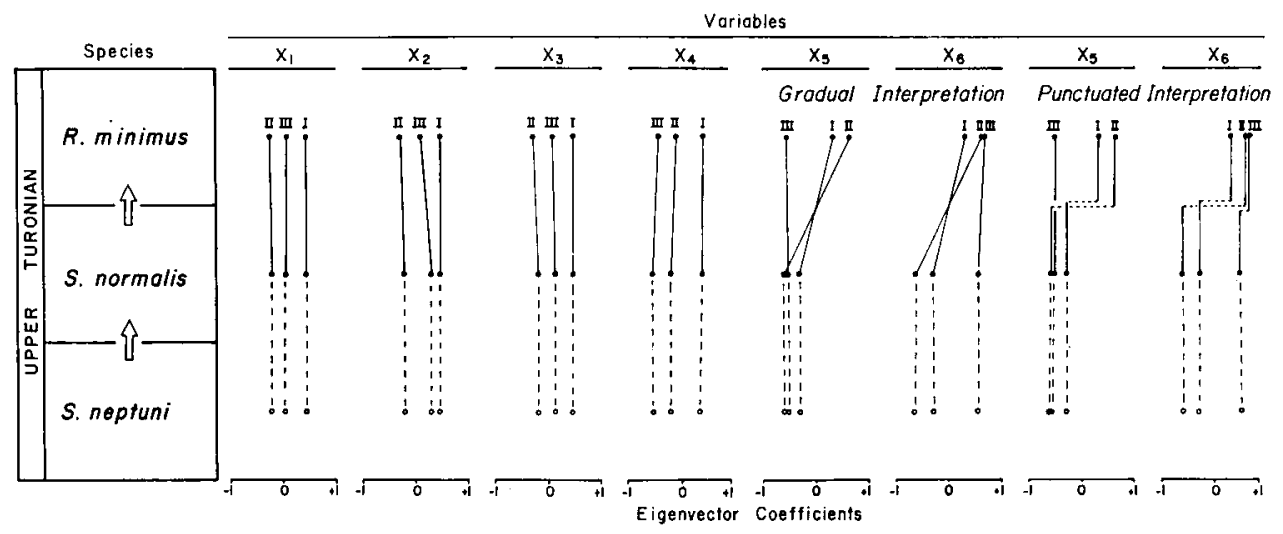

FIG. 1. Change in eigenvector coefficients of principal component analysis, plotted stratigraphically, for a sample of Subprionocyclus normalis and a sample of Reesidites minimus (solid circles). S. neptuni (open circles) assumed to differ little from S. normalis. Eigenvectors I-III include $97 \%$ of total variance, data from Reyment (1975). Note little change in eigenvector coefficients associated with size and shape variables $\left(X_{1}-X_{4}\right)$, but reversal of sign in coefficients of eigenvectors $I$ and II associated with ornamentation variables $\left(X_{5}\right.$ and $\left.X_{6}\right)$. Alternative gradual or punctuated interpretations of change in the coefficients associated with $X_{5}$ and $X_{6}$ are given at right of diagram, but present evidence is insufficient to permit one to choose between them.

(1975). In brief, three species of an ammonite lineage Subprionocyclus neptuni, Subprionocyclus normalis, and Reesidites minimus succeeded each other in the Upper Turonian (mid Cretaceous) of the Pacific and Indian Ocean basins. Details regarding the thickness of sampled stratigraphic levels and the intervals between levels are not given in the available literature. Judging from Matsumoto (1959) and Obata (1965), S. normalis and $R$. minimus occur within horizons on the order of $1 \mathrm{~m}$ thick in a section on the order of $10 \mathrm{~m}$ thick, but this varies from locality to locality. No estimate is given of the amount of time represented by the sampled sections. Following a detailed multivariate analysis, Reyment concluded that the three species under study differed little in size and shape, but that an abrupt reversal in the underlying relationship of shape and ornamentation between $S$. normalis and $R$. minimus justified retaining Reesidites as a distinct genus. The only conclusion I wish to question is the "abruptness" of the transition from Subprionocyclus to Reesidites, and citation of this as an example of "punctuated equilibria" in the fossil record.

The evidence bearing on the transition from Subprionocyclus to Reesidites, studied by principal components analysis, is summarized in Reyment's Table 3 and his Figure 6 in the form of calculated coefficients or loadings of each eigenvector (I-VI) corresponding to each original variable $\left(X_{1}-X_{6}\right)$. A total of $97 \%$ of the total variance is contained in the first three eigenvectors.
In Fig. 1 I have replotted Reyment's coefficients, this time in stratigraphic order, for eigenvectors I, II, and III. Subprionocyclus neptuni was not actually included by Reyment, but it is implicit in his analysis that it differed little from $S u b$ prionocyclus normalis.

The original variables $X_{1}-X_{4}$ were logarithmically transformed linear measurements to quantify size and shape. As stated by Reyment, and shown in Fig. 1, the eigenvector coefficients for each variable $X_{1}-X_{4}$ changed very little in going from Subprionocyclus normalis to Reesidites minimus. Variables $X_{5}$ and $X_{6}$ measured the number of umbilical and vertrolateral tubercles, respectively, and the loadings of eigenvectors I and II for these variables differed greatly in S. normalis and $R$. minimus, reversing from negative to positive sign in each case. This is the basis for Reyment's statement that the transition from one species to the other was an abrupt reversal of the relationship between shape and ornamentation.

The available data (Fig. 1) show that Reesidites minimus differed significantly from $S u b$ prionocyclus normalis in the relationship of shape and ornamentation, but nothing is indicated about the nature of the transition from one species to the other. Both a gradual interpretation and a "punctuated" interpretation are illustrated in Fig. 1 for the coefficients associated with variables $X_{5}$ and $X_{6}$-which interpretation is the correct one cannot be determined until a series of samples are found stratigraphically and temporally intermediate between the two samples analyzed by 
Reyment. It is evidently not possible at present to subdivide collections from the $S$. normalis and $\boldsymbol{R}$. minimus zones into successive subsamples spanning the same interval, and until additional intermediate samples are available, nothing can be said of the mode of transition from one species to the other. 'Two points on a graph do not determine the path of a line connecting them, and two samples in the fossil record cannot reveal the transition from one species to another.

\section{ACKNOWLEDGMENTS}

I thank Professor R. A. Reyment and Mr. Niall Mateer, Paleontologiska Institutionen, Uppsala, for discussion of the substance of this note. Drs. Niles Eldredge, Brian Glenister, and David M. Raup read and improved the manuscript.

\section{Literature Cited}

Eldredge, N. 1971. The allopatric model and phylogeny in Paleozoic invertebrates. Evolution 25:156-167.

Eldredge, N., aNd S. J. Gould. 1972. Punctuated equilibria: An alternative to phyletic gradualism, p. 82-115. In T. J. M. Schopf (ed.), Models in Paleobiology. Freeman, Cooper \& Co., San Francisco.

Gingerich, P. D. 1976a. Paleontology and phylogeny: Patterns of evolution at the species level in early Tertiary mammals. Amer. J. Sci. 276:1-28.

- 1976b. Cranial anatomy and evolution of early Tertiary Plesiadapidae (Mammalia, Primates). Univ. Michigan Papers Paleontol. $15: 1-140$.

Gould, S. J., and N. Eldredge. 1977. Punctuated equilibria: The tempo and mode of evolution reconsidered. Paleobiology 3:115151.

Matsumoto, T. 1959. Zonation of the Upper Cretaceous of Japan. Mem. Fac. Sci. Kyushu Univ. (D) 9:55-93.

Obata, I. 1965. Allometry of Reesidites minimus, a Cretaceous ammonite species. Trans. Proc. Palaeont. Soc. Japan, N.S. 58:39-63.

Reyment, R. A. 1975. Analysis of a generic level transition in Cretaceous ammonites. Evolution 28:665-67\%.

SImpson, G. G. 1951. The species concept. Evolution 5:285-298.

Evolution, 32(2), 1978, pp. 456-458

\title{
WHY ARE THERE INBREEDING EFFECTS IN HAPLO-DIPLOID SYSTEMS?
}

\author{
DOROTHEA BRÜCKNER \\ Zoologisches Institut d. Universität, Seidlstr. 25, 8 München 2, FRG
}

Received November 22, 1976. Revised August 5, 1977

In haplo-diploid systems one part of the population, the male sex is always haploid (hemizygous). In haploid individuals all genes act like dominants, there is no suppression of deleterious recessive alleles by normal dominants. Since the sperm cells are identical in genotype to the male that produces them, beneficial genes are likely to be spread more rapidly in haplo-diploid than in diploid systems whereas disadvantageous genes should not be able to accumulate in such a species. Haplo-diploid species also differ from diploid species in the fact that heterotic mechanisms can be effective only in the diploid part of the population. Traits that are important to both parts of the population should not rely on heterosis. It was argued on theoretical grounds that variability maintained by overdominance should be reduced by haplo-diploidy (Hartl, 1971).

Both the possible reduction of disadvantageous recessive alleles and the possibly decreased im- portance of heterotic mechanisms could have implications for the effects of inbreeding in haplodiploid systems. It is a common argument that inbreeding depression in diploid species is caused by the appearance of 'hidden' deleterious alleles and by the breakdown of heterotic mechanisms. It then follows that haplo-diploid systems should be less affected by inbreeding, the haploid part of the population experiencing conditions that are similar to the homozygous condition of individuals from inbred diploid species.

Nevertheless mechanisms are found in the natural history of many highly social haplo-diploid insects that tend to prevent inbreeding, in honeybees, for example, the following: no mating of queens in the hives, congregation areas of drones, long distance nuptial flights of queens and multiple insemination of queens (Ruttner, F. and Ruttner, H., 1965; Woyke, 1955). Therefore the following questions were asked: What are the effects 